Archives of Agriculture and Environmental Science

\title{
Application of coconut shell charcoal and NPK fertilizer toward Acacia mangium growth on the soil of ex-limestone mining in Bogor, Indonesia
}

\section{Basuki Wasis ${ }^{*}$ (D) , Siti Hanna Ghaida and Bayu Winata}

Department of Silviculture, Faculty of Forestry, Bogor Agricultural University. Jl. Lingkar Kampus, Kampus IPB Darmaga, Bogor 16680, West Java, INDONESIA

*Corresponding author's E-mail: basuki_wasis@yahoo.com

\section{ARTICLE HISTORY}

Received: 12 February 2019

Revised received: 27 February 2019

Accepted: 02 March 2019

\section{Keywords}

Acacia mangium

Coconut shell charcoal

Lime mining

NPK fertilizer

Revegetation

\begin{abstract}
Limestone mining is an activity that can cause damage and negative impact on the environment. Revegetation is needed to be done so that the damaged land condition can be returned in accordance with its designation. Acacia mangium is one of the species that can be used in revegetation of mining area. This study aims to increase the A. mangium growth response at the limestone mining land that can be used as a tool for consideration in revegetation activities. The design used in this experiment was a complete randomized design (CRD) factorial with 2 factors. The first factor was the application of coconut shell charcoal and the second factor was the application of NPK fertilizer. The results showed that the addition of coconut shell charcoal could give effect to the number of nodules with the best dose of $90 \mathrm{~g}$ and NPK fertilizer was able to give effect to the growth of diameter and the number of root nodules with the best dose of $15 \mathrm{~g}$.
\end{abstract}

(C)2019 Agriculture and Environmental Science Academy

Citation of this article: Wasis, B., Ghaida, S.H. and Winata, B. (2019). Application of coconut shell charcoal and NPK fertilizer toward Acacia mangium growth on the soil of ex-limestone mining in Bogor, Indonesia. Archives of Agriculture and Environmental Science, 4(1): 75-82, https://dx.doi.org/10.26832/24566632.2019.0401012

\section{INTRODUCTION}

Gunung Kapur Ciampea - Bogor is an limestone ecosystem. Based on its biophysical condition, the land cover (vegetation) should be maintained in the form of forest. Forest play important role in the life support systems, especially the function of the water system (hido-orology system) in the ecosystem. Forest conversion into other uses can threaten the existence of forest vegetation and environmental functions (Oksana et al., 2012). At Gunung Kapur Ciampea has been granted permission for lime mining activities. Mining causes damage and negative impacts to the environment such as decreasing soil productivity, sedimentation, landslides, damage to flora and fauna, and changes the microclimate (Cakyayanti and Setiadi, 2014, Wasis and Andika, 2017).

Lime rock is a $C$ extract that is widely used in industrial or production activities (Sukandarrumidi, 2009). The high lime mining activities may result in the damage to vegetation and soil horizon, loss of top soil, low organic matter, high $\mathrm{pH}$, high soil temperature, trace deposits, and low diversity of soil microbial populations (Prayudyaningsih, 2014). Therefore, to be able to restore the function of damaged ecosystems needs to be done rehabilitation activities in the form of land improvement and tree planting (revegetation). Land improvement is needed to repair the damaged soil, one of them are with the addition of coconut shell charcoal or NPK fertilizer. Coconut shell charcoal plays a role in increasing fertility and plant growth. Bio-charcoal has a more effective capability in reducing nitrogen nutrient leaching compared to rice husk charcoal (Hariz et al., 2015). NPK fertilizers include inorganic compounds that play a role in increasing the amount of nutrients in the soil (Liliane et al., 2001, Atkinson et al., 2010). This fertilizer is easily dissolved in water and quickly absorbed by plants.

Revegetation is an activity that has the potential to restore and improve the productivity of land that has been damaged by mining. The success of revegetation depends on the selection of plant species capable of recovering soil damage and its adaptability on the soil characteristics, climate, and the ultimate goal of revegetation (Cakyayanti and Setiadi, 2014; Wasis and Andika, 2017). One of the most potentially species selected for 
revegetation is Acacia mangium. A. mangium is a fast growing plants that can grow well in marginal pastures and mining sites (Yamashita et al., 2008; Aggangan et al., 2010). The form of adaptation by this species is symbiotic with rhizobium bacteria and forming root nodules on its root system. This study aims to examine the growth response of $A$. mangium on the ex-limestone mining media (soil) as well as the influence of coconut shell charcoal and NPK fertilizer on A. mangium growth.

\section{MATERIALS AND METHODS}

\section{Experimental design}

The research was conducted from February - July 2017 at Greenhouse of Silviculture Division and Forest Influence Laboratory, Department of Silviculture, Faculty of Forestry, Bogor Agicutural University (IPB). The materials used were A. mangium seedlings (3 month), coconut shell charcoal, NPK fertilizer, water, and media/ soil (from ex-limestone mining land in Ciampea, Bogor, West Java), polybag, digital scales, sprinkler, calipers, rulers, calculators, oven. Observed parameters were growth of height, diameter, shoot root ratio, number of root nodule, biomass (dry and wet weight), and nutrient content in media. Generally, the procedure of this research were as follows:

\section{Media preparation and planting}

The soil from ex-limestone mining were weighed as $1 \mathrm{~kg}$ in dry air condition and mixed with coconut shell charcoal and NPK fertilizer. Dose of each coconut shell charcoal applications were $0 \mathrm{~g}, 30 \mathrm{~g}, 60 \mathrm{~g}$, and $90 \mathrm{~g}$. Dose of each NPK fertilizer applications were $0 \mathrm{~g}, 5 \mathrm{~g}, 10 \mathrm{~g}$, and $15 \mathrm{~g}$. A. mangium seedlings were planted into 48 prepared polybags (media) in the previous stage.

\section{Data collection}

Data collection was done by doing measurement of height and diameter of the seedlings. Beside that, total wet weight (TWW) and total dry weight (TDW) measurements were done after the harvesting. The harvested plants were separated between the root and shoot. Each part (root and shoot) was weighed using a digital scales. TWW was the sum of the weight of wet roots and wet shoot weight. TDW was measured after the plant part was dried in an oven at $70^{\circ} \mathrm{C}$ for 24 hours and then weighed using a digital scales. TDW was the sum of root dry weight and shoot dry weight. The calculation of the number of root nodules was done by counting the root nodules on each root of the plant observed. The root shoot ratio was calculated based on the ratio of the total dry weight of the shoot to the total dry weight value of the root. The analysis of nutrient content (in the media/soil) was conducted at the Laboratory of the Department of Soil Science and Land Resources, Faculty of Agriculture, IPB.

\section{Data analysis}

This experiment used completely randomized design factorial with 2 factors. Each treatment was done by 3 repetitions. The first factor was coconut shell charcoal $\left(A_{0}=0 \mathrm{~g}, A_{1}=30 \mathrm{~g}, A_{2}=\right.$ $60 \mathrm{~g}$, and $\left.A_{3}=90 \mathrm{~g}\right)$. The second factor was NPK fertilizer $\left(P_{0}=0\right.$ $\mathrm{g}, \mathrm{P}_{1}=5 \mathrm{~g}, \mathrm{P}_{2}=10 \mathrm{~g}$, and $\mathrm{P}_{3}=15 \mathrm{~g}$ ). To analyze the treatment effect on each growth parameter observed, we used ANOVA analysis and Duncan's Multiple Range Test to knowing the best treatment which affect the A. mangium's growth. (Mattjik and Sumertajaya 2013; Stell and Torries 1991; Wibisono, 2009)

\section{RESULTS AND DISCUSSION}

The result of this study that showing the effect of coconut shell charcoal and NPK toward the growth of A. mangium was showed on Table 1.

This study showed that the addition of coconut shell charcoal gave a significant effect on the number of root nodule of $A$. mangium seedlings. The addition of NPK fertilizer gave a different effect on the growth of diameter and number of root nodule of A. mangium. Meanwhile, for the combination of coconut shell charcoal addition and NPK fertilizer did not give any significant effect on all parameters. This study also showed that A. mangium could grow on media of ex-limestone mine. Growth is an increase in plant dimension that was influenced by genetic and environmental factors. This genetic factor is brought by plants that are inherited directly from the elder, while the environmental factor was the result of modification of the habitat of a plant (Wasis and Andika, 2017). A. mangium is a plant that able to grow well in critical land. This species has a good adaptability in various soil types and environmental conditions including limestone minerals (Krisnawati et al., 2011; Prayudyaningsih, 2014).

Table 1. Effect of coconut shell charcoal and NPK fertilizer impact on growth of A. mangium seedlings.

\begin{tabular}{lccc}
\hline \multirow{2}{*}{ Parameter } & \multicolumn{2}{c}{ Treatment } \\
\cline { 2 - 3 } & Coconut shell charcoal & NPK fertilizer & Coconut shell charcoal and NPK fertilizer \\
\hline Height & $0.8056^{\text {tn }}$ & $0.8744^{\text {tn }}$ & $0.9138^{\text {tn }}$ \\
Diameter & $0.7157^{\text {tn }}$ & $0.0336^{*}$ & $0.3376^{\text {tn }}$ \\
Total wet weight & $0.7941^{\text {tn }}$ & $0.8532^{\text {tn }}$ & $0.2626^{\text {tn }}$ \\
Total dry weight & $0.6562^{\text {tn }}$ & $0.6189^{\text {tn }}$ & $0.3055^{\text {tn }}$ \\
Root shoot ratio & $0.3029^{\text {tn }}$ & $0.7352^{\text {tn }}$ & $0.8823^{\text {tn }}$ \\
Number of root nodules & $0.0192^{*}$ & $0.0334^{*}$ & $0.3220^{\text {tn }}$ \\
\hline
\end{tabular}

Remarks: ${ }^{*}=$ treatment had significant effect on $95 \%$ confidence interval with significant value $(P$-value $)<0.05(\alpha)$. th $=$ treatment had no significant effect on $95 \%$ confidence interval with significant value (P-value) $>0.05(\alpha)$ 

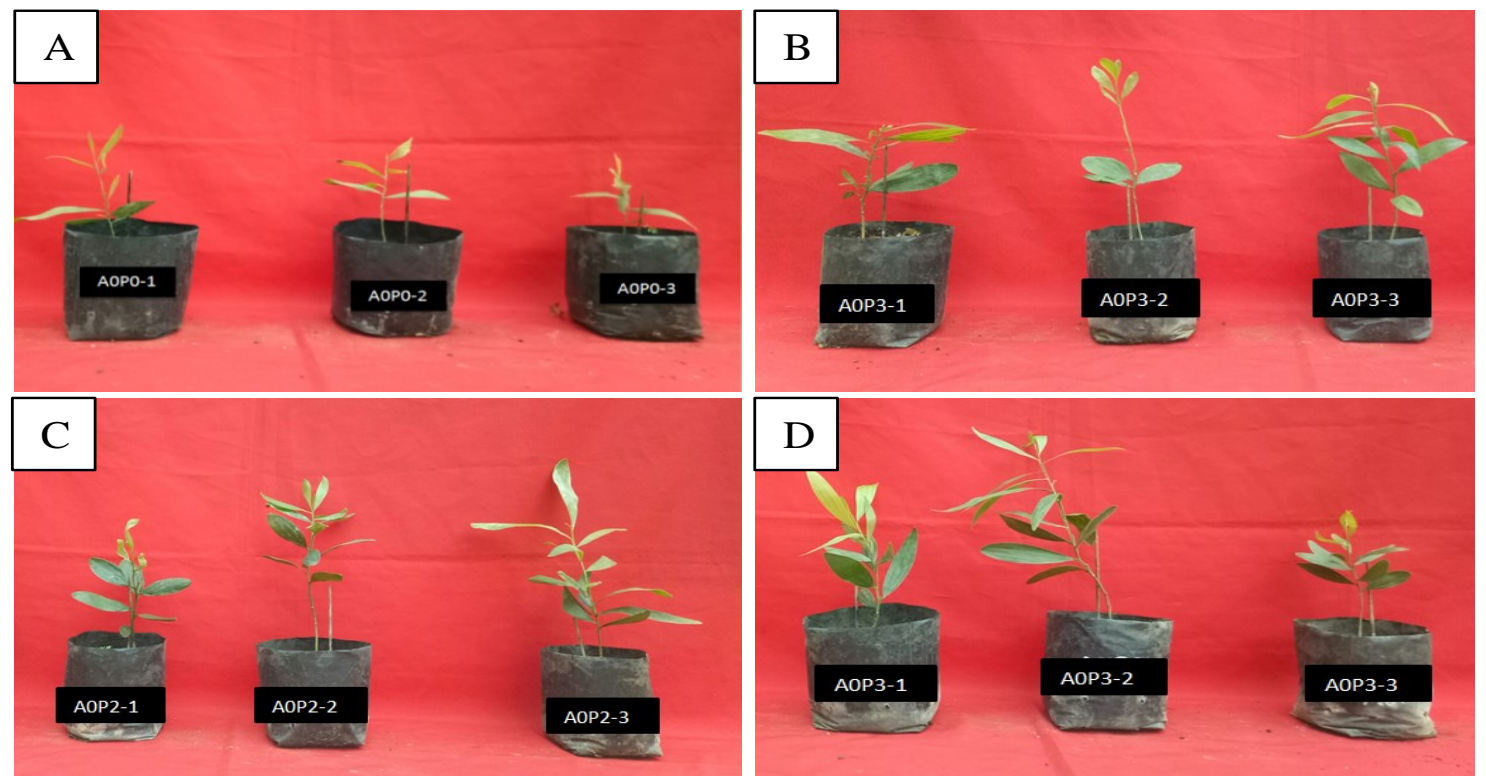

Figure 1. Growth of A. mangium with the addition of NPK fertilizer dosage $0 g(A)$, dose $5 g(B)$, dose $10 g(C)$, and dose $15 g(D)$.

Table 2. Duncan test results of the effect of NPK fertilizer on the growth of seed diameter A. mangium.

\begin{tabular}{lcc}
\hline Treatment NPK fertilizer & Average diameter growth $(\mathrm{cm})$ & Percent increase $(\%)$ \\
\hline Dose of $0 \mathrm{~g}$ & $0.68 \mathrm{~b}$ & 0.00 \\
Dose of $5 \mathrm{~g}$ & $0.70 \mathrm{~b}$ & 2.94 \\
Dose of $10 \mathrm{~g}$ & $1.02 \mathrm{ab}$ & 50.00 \\
Dose of $15 \mathrm{~g}$ & $1.19 \mathrm{a}$ & 75.00 \\
\hline
\end{tabular}

Remarks: Number followed by the same letter showed no significant different treatment at $95 \%$ confidence interval.

Table 3. The average of root-shoot ratio and the comformity to planted of A. mangium.

\begin{tabular}{lll}
\hline Treatment & Root shoot ratio & Conformity to planted \\
\hline $\mathrm{A}_{2} \mathrm{P}_{1}$ & 2.70 & Suitable \\
$\mathrm{A}_{1} \mathrm{P}_{2}$ & 3.25 & Not suitable \\
$\mathrm{A}_{1} \mathrm{P}_{3}$ & 3.53 & Not suitable \\
$\mathrm{A}_{3} \mathrm{P}_{3}$ & 3.56 & Not suitable \\
$\mathrm{A}_{2} \mathrm{P}_{0}$ & 3.64 & Not suitable \\
$\mathrm{A}_{1} \mathrm{P}_{1}$ & 3.68 & Not suitable \\
$\mathrm{A}_{3} \mathrm{P}_{0}$ & 3.79 & Not suitable \\
$\mathrm{A}_{3} \mathrm{P}_{2}$ & 3.88 & Not suitable \\
$\mathrm{A}_{2} \mathrm{P}_{3}$ & 3.91 & Not suitable \\
$\mathrm{A}_{1} \mathrm{P}_{0}$ & 4.05 & Not suitable \\
$\mathrm{A}_{3} \mathrm{P}_{1}$ & 4.10 & Not suitable \\
$\mathrm{A}_{0} \mathrm{P}_{3}$ & 4.19 & Not suitable \\
$\mathrm{A}_{0} \mathrm{P}_{1}$ & 4.20 & Not suitable \\
$\mathrm{A}_{0} \mathrm{P}_{0}$ & 4.53 & Not suitable \\
$\mathrm{A}_{2} \mathrm{P}_{2}$ & 4.56 & Not suitable \\
$\mathrm{A}_{0} \mathrm{P}_{2}$ & 5.12 & Not suitable \\
\hline
\end{tabular}

Remarks : Suitable $=$ Root shoot ratio 1-3; Not suitable $=$ Root shoot ratio $>3$.

Duncan test results (Table 2 and Figure 1) showed that the average growth of diameter of $A$. mangium on ex-limestone mining soil with $0 \mathrm{~g}$ NPK fertilizer (control soil) had no significant effect on soil with $5 \mathrm{~g} \mathrm{NPK}$ (2.94\%) and $10 \mathrm{~g}$ NPK (50\%). However treatment with 15 g NPK had a significant effect on the growth of diameter (75\% from the control). It showed that A. mangium had the best diameter growth if planted on ex-limestone mining soil with the addition of $15 \mathrm{~g}$ of NPK fertilizer. In the other hand, the lowest diameter growth of $A$. mangium planted on ex-limestone mining soil was showed by the treament of the addition of $5 \mathrm{~g}$ NPK fertilizer. Achiri et al. (2017) said that the addition of NPK fertilizer affects to the growth of stem diameter. Nutrient content of $\mathrm{N}, \mathrm{P}$, and $\mathrm{K}$ have a great influence on the increase of stem diameter (Siregar and Utami, 2002; Herdiana et al., 2008; Prayudyaningsih 2014).
Table 3 showed that the addition of coconut shell charcoal and NPK fertilizer had hight effect toward root shoot ratio (from 3.25 to 5.12), except $A_{2} P_{1}$ treatment gave effect as 2.70 . These results showed that shoot biomass was greater than that of root biomass, generally in this research. The results of this study indicated that root growth was very low as a result of low availability of water and nutrients generally in the medium of limestone soil. The value of root shoot ratio can be used to see the balance between root capability in absorbing water and nutrients as well as the ability of plant shoot in the process of transpiration and the rate of photosynthesis (Wahyudi, 2009; Wulandari and Susanti, 2012). Plant growth is called has well performance when it has a value of shoot root ratio ranging from 1-3 (Mokany et al., 2006, Wasis and Andika, 2017). 
Duncan test results (Table 4) showed that the number of root nodules of $A$. mangium seedlings on ex-limestone mine media by the addition $0 \mathrm{~g}$ of coconut shell charcoal (control) did not give significantly different effect with the $30 \mathrm{~g}$ coconut shell charcoal. However $60 \mathrm{~g}$ and $90 \mathrm{~g}$ coconut soil caharcoal additions gave a significantly different effect on the number of root nodule. These results showed that by increasing doses of coconut shell charcoal could increase the number of root nodule of $A$. mangium seedling. Bio-charcoal has a porous structure and a large surface area that provides such advantages as a habitat for the root nodule-forming bacteria, stimulates nodulation and fixation, and modifies the availability of $\mathrm{N}$ in the soil to be utilized by plants (Atkinson et al., 2010, Ogawa and Okimori, 2010, Pereyra et al., 2015).

Table 5 showed that the number of root nodule of $A$. mangium on ex-limestone mining media with NPK fertilizer dose $0 \mathrm{~g}$ (control) did not give significantly different effect with the addition of $5-10 \mathrm{~g}$ NPK fertilizer. However the addition of 15 g NPK fertilizer was significantly effected on the root nodule number of $A$. mangium. This treatment could produce $145.45 \%$ increase of root nodule from the control treatment. The addition of NPK fertilizer in the media/soil was able to trigger the formation of root nodules. This phenomenon was indicated by the significant influence on the formation of the number of root nodule of A. mangium. Nutrients that played a role in the formation of the number of root nodules was phosphorus. This $\mathrm{P}$ element is indispensable for rapid and healthy root development and stimulates the formation of root nodule by Rhizobium sp. bacteria. (Singh et al., 2007).

Tabel 6 showed the soil properties analysis on the media. This analysis compared the control treatment and the treatment with $60 \mathrm{~g}$ coconut shell charcoal $\left(\mathrm{A}_{2}\right)$ and $5 \mathrm{~g}$ NPK fertilizer $\left(\mathrm{P}_{1}\right)$. The $A_{2} P_{1}$ treatment was the best treatment which could produced the best root shoot ratio growth. Soil texture was determined by using the diagram of USDA soil texture triangle. Control treatment had sandy clay loam texture with $52.15 \%$ sand, $22.24 \%$ silt, and $25.61 \%$ clay. On the other hand, the addition of coconut shell charcoal and NPK fertilizer $\left(\mathrm{A}_{2} \mathrm{P}_{1}\right.$ treatment) had loam texture with $47.46 \%$ sand, $30.51 \%$ silt, and $22.13 \%$ clay. Loam soil is ideal soil texture to support the plant growth, and generally it contains $22.5-52.5 \%$ sand, $30-50 \%$ silt, and 10-30\% clay (Hardjowigeno, 2003; Hanafiah, 2005).

Organic $\mathrm{C}$ is an organic material that has an important role in the soil, especially in providing essential nutrients with sufficient quantities for plant growth (Wasis and Noviani, 2010; Wulandari et al., 2102). The result of soil chemical analysis showed that the control soil contained very low organic $C(0.82 \%)$, while on the soil given the addition of coconut shell charcoal and NPK fertilizer $\left(\mathrm{A}_{2} \mathrm{P}_{1}\right)$ had a high organic $\mathrm{C}$ content (3.27\%). The high content of organic $C$ in the soil might be caused by the addition of coconut shell charcoal. Coconut shell has highest chemical component such as lignin (Rodrigues and Pinto, 2007). Lignin is a compound that acts as an organic C-source (Kusuma et al., 2013). N element is an essential nutrient that needed by plants. The function of the $\mathrm{N}$ element is to improve and stimulate the growth of stems, branches, leaves and assist in the establishment of protein (Hardjowigeno, 2003; Lingga and Marsono, 2008). The result of soil chemical analysis showed that the control soil had a very low $\mathrm{N}$-total content $(0.08 \%)$, while media/soail with the addition of coconut shell charcoal and NPK fertilizer had a moderate $\mathrm{N}$-total content $(0.21 \%)$. This phenomenon showed that coconut shell charcoal and NPK fertilizer could increase the N content in the soil. Nitrogen can improve the process of photosynthesis, increasing the number of leaves, and the plant could growth optimally (Mansur, 2013).

In other hand, the addition of coconut shell charcoal and NPK fertilizer is also able to increase the $P$ content in the soil. $P$ element has a function to strengthen the stem, cell division, and root development (Hardjowigeno, 2003). The content of $P$ available in the control was 120.03 ppm, while on the soil with the addition of coconut shell charcoal and NPK fertilizer had a higher P content (172.19 ppm). Coconut shell charcoal and NPK fertilizer contain phosphorus that can be utilized by plant growth. The use of NPK fertilizer and coconut shell charcoal can increase $\mathrm{P}$ content especially in poor nutrient soil (Gani, 2009; Roidah, 2013). The cation exchange capacity (CEC) is the number of cations that can be absorbed by the soil per unit of soil weight, CEC value can be used in determining the high level

Table 4. Duncan test results of coconut shell charcoal effect on the number of root nodules of $A$. mangium seedlings.

\begin{tabular}{lcc}
\hline Treatment coconut shell charcoal & Number of root nodule & Percent increase (\%) \\
\hline Dose of $0 \mathrm{~g}$ & $3.08 \mathrm{~b}$ & 0.00 \\
Dose of $30 \mathrm{~g}$ & $6.08 \mathrm{ab}$ & 97.40 \\
Dose of $60 \mathrm{~g}$ & $11.50 \mathrm{a}$ & 273.38 \\
Dose of $90 \mathrm{~g}$ & $11.58 \mathrm{a}$ & 275.97 \\
\hline
\end{tabular}

Remarks: Number followed by the same letter showed no significant different treatment at $95 \%$ confidence interval.

Table 5. Duncan test results of NPK fertilizer effect on the number of root nodule of A. mangium seedlings.

\begin{tabular}{lcc}
\hline Treatment NPK fertilizer & Number of root nodules & Percent increase (\%) \\
\hline Dose of $0 \mathrm{~g}$ & $5.50 \mathrm{~b}$ & 0.00 \\
Dose of $5 \mathrm{~g}$ & $5.00 \mathrm{~b}$ & -9.09 \\
Dose of $10 \mathrm{~g}$ & $8.25 \mathrm{ab}$ & 50.00 \\
Dose of $15 \mathrm{~g}$ & $13.50 \mathrm{a}$ & 145.45 \\
\hline
\end{tabular}

Remarks : Number followed by the same letter showed no significant different treatment at $95 \%$ confidence interval. 
of soil fertility (Hardjowigeno, 2003). The result of soil analysis showed that CEC found in control and soil with the addition of coconut shell charcoal and NPK fertilizer had high CEC value were $36.01 \mathrm{me} / 100 \mathrm{~g}$ and $35.09 \mathrm{me} / 100 \mathrm{~g}$, respectively. Those CEC condition were caused by soil condition which dominated by basic cations such as $\mathrm{K}, \mathrm{Na}, \mathrm{Mg}$, and $\mathrm{Ca}$. Soil with high $\mathrm{CEC}$ is dominated by alkaline cations will have high alkali saturation (Hardjowigeno, 2003). This condistion also supported by the presence of clay fraction with negative charges, so the cation excahange will be higher (Dharmawan and Siregar, 2008, Wasis and Noviani, 2010).

Based on the cation arrangement, the control soil contains elements of $\mathrm{K}(0.83 \mathrm{me} / 100 \mathrm{~g}), \mathrm{Na}(0.86 \mathrm{me} / 100 \mathrm{~g}), \mathrm{Mg}(2.36$ $\mathrm{me} / 100 \mathrm{~g})$, and $\mathrm{Ca}(78.27 \mathrm{me} / 100 \mathrm{~g})$. Soil with the addition of coconut shell and NPK fertilizer contained elements of $\mathrm{K}, \mathrm{Na}$, and $\mathrm{Ca}$ were very high (Table 6). The addition of coconut shell charcoal and NPK fertilizer were able to increase the element $\mathrm{K}$, $\mathrm{Na}, \mathrm{Mg}$ in the soil. Element $\mathrm{K}$ plays a role in the opening of stomata, root development, and increase resistance to drought and disease, while $\mathrm{Mg}$ plays a role in the formation of chlorophyll and activator enzyme that closely related to the metabolism of carbohydrates (Hardjowigeno, 2003; Kastono, 2005). Na element is able to give effect to plant growth and production, but if $\mathrm{Na}$ ratio with other cation is too high then plant growth can be hampered (Hanafiah, 2005). Different with $\mathrm{K}, \mathrm{Na}$, and $\mathrm{Mg}$ elements, $\mathrm{Ca}$ in the ex-limestone mining soil was decreasing when the soil was treated by the addition of coconut shell charcoal and NPK fertilizer. However, $\mathrm{Ca}$ in the soil with the addition of coconut shell charcoal and NPK was still high. Ca with high condition due to an inhibition on A. mangium growth.
White and Broadley (2003) said when Ca element was so high, it can be a toxic to the plant.

Soil $\mathrm{pH}$ balance played a role in supporting plant growth due to soil $\mathrm{pH}$ could describe the condition of macro and micro nutrient availability in the soil. The soil chemical analysis results showed that the control soil has a neutral $\mathrm{pH}$ value (7.42), as well as with soil enhanced coconut shell charcoal and NPK fertilizer which has a neutral $\mathrm{pH}$ value (7.03). Soil with neutral $\mathrm{pH}$ has the ability to provide optimal nutrient for plant growth (Nduwumuremyi, 2013). In addition, soil pH also played a role to support the root nodules establishement which has symbiosis with rhizobium bacteria in the soil. Rhizobium bacteria are able to grow well in soil with neutral $\mathrm{pH}$. Wadhwa et al. (2017) said the optimum $\mathrm{pH}$ that supports rhizobial growth is about 6-7, while the minimum growth is about $\mathrm{pH} 8$ and $\mathrm{pH}$ 9. Organism activities in the soil could be used as an indicators of soil quality. The benefits of soil organisms are to support the process of nutrient cycling, modification of soil structure, nitrogen fixation, soil decomposition, soil structure dynamics, and symbiosis with plants (Widyati, 2013; Barrios, 2007; Wasis et al., 2018). Coconut shell charcoal on marginal soil (ex-limestone mining soil) could invite the presence of soil organisms. Bio-charcoal has a function as a habitat for soil organisms and support their life cylce (Shalsabila et al., 2017). The soil organisms that found in the media were ants and earthworms. Ant is able to increase soil porosity, influence $\mathrm{pH}$ to be neutral, and increase nutrient content in soil (Frouz and Jilkova, 2008). Earthworms are a species that potentially to increase porosity and soil aggregation, and can play a role in restoring mine land (Shipitalo, 2004, Boyer and Wratten, 2009).

Table 6. Soil (planting media) properties analysis.

\begin{tabular}{|c|c|c|c|c|c|}
\hline Number & Treatment & Control & Criteria* & $\begin{array}{l}\text { Coconut shell charcoal and } \\
\text { NPK fertilizer }\left(A_{2} P_{1}\right)\end{array}$ & Criteria* \\
\hline \multirow[t]{4}{*}{1} & Texture (\%) & & & & \\
\hline & Sand & 52.15 & & 47.36 & \\
\hline & Silt & 22.24 & Clay loam & 30.51 & Sandy clay loam \\
\hline & Clay & 25.61 & & 22.13 & \\
\hline 2 & Organic C (\%) & 0.82 & Very low & 3.27 & $\mathrm{High}^{*}$ \\
\hline 3 & Nitrogen (N)-total (\%) & 0.08 & Low & 0.21 & Medium \\
\hline 4 & Phosphorus (P) (ppm) & 120.03 & Very high & 172.19 & Very high \\
\hline 5 & $\mathrm{CEC}(\mathrm{me} / 100 \mathrm{~g})$ & 36.01 & High & 35.09 & High $^{*}$ \\
\hline 6 & $\mathrm{pH}$ & 7.42 & Netral & 7.03 & Netral $^{*}$ \\
\hline \multirow[t]{5}{*}{7} & Cation & & & & \\
\hline & $\begin{array}{l}\text { Potasium (K) } \\
\text { (me/100g) }\end{array}$ & 0.83 & High & 5.29 & Very high \\
\hline & $\begin{array}{l}\text { Sodium (Na) } \\
(\mathrm{mg} / 100 \mathrm{~g})\end{array}$ & 0.86 & High & 1.63 & Very high tinggi \\
\hline & Magnesium (Mg) (me/100g) & 2.36 & High & 3.41 & High \\
\hline & $\begin{array}{l}\text { Calcium (Ca) } \\
\text { (me/100g) }\end{array}$ & 78.27 & Very high & 68.97 & Very high \\
\hline 8 & Alumunium (Al) (me/100g) & $\operatorname{Tr}$ & - & $\operatorname{Tr}$ & - \\
\hline 9 & Alkali Saturation (\%) & 100 & Very high & 100 & Very high \\
\hline
\end{tabular}

Remarks : ${ }^{*}$ Criteria based on Balai Penelitian Tanah (2009) ; Tr = not measurable. 
Conclusion

The single increment of coconut shell charcoal or NPK fertilization in the ex-limestone mining media gave a significant effect toward the growth of $A$. magium seedling, especially on its diameter growth and root nodule number. The best treatment for increasing the seedling's diameter growth was $15 \mathrm{~g}$ NPK, where this treatment was not significantly different with $10 \mathrm{~g}$ NPK increment. In addition, these treatments also gave the best result on the root nodule growth. In other hand, the treatment of $90 \mathrm{~g}$ coconut shell charcoal addition also gave the best the growth of diameter. This treatment was not significantly different with $60 \mathrm{~g}$ coconut shell charcoal addition. Generally, the increment of coconut shell charcoal and/or NPK fertilization could be supporting the growth of $A$. mangium seedling, also improving the soil (ex-limestone mining media) characteristic.

\section{ACKNOWLEDGEMENT}

We would like to thank to the Forest Ecology Laboratory, Forest Influence Laboratory, and the chairman of Department of Silviculture, Bogor Agricultural Institute (IPB). Without their help and support, this research would not have been possible.

Open Access: This is an open access article distributed under the terms of the Creative Commons Attribution 4.0 License, which permits unrestricted use, distribution, and reproduction in any medium, provided the original author(s) if the sources are credited.

\section{REFERENCES}

Achiri, D.T., Mbaatoh, M.H., Njualem, D. (2017). Agronomic and yield parameters of $\mathrm{CHC} 202$ maize (Zea mays $\mathrm{L}$ ) variety influenced by different doses of chemical fertilizer (NPK) in Bali Nyonga, North West Region Cameroon. Asian Journal of Soil Science and Plant Nutrition 2(4): 1-9, https://doi.org/10.9734/AJSSPN/2017/39583

Aggangan, N.S., Moon, H.K. and Han, S.H. (2010). Growth response of Acacia mangium Willd. seedlings to arbuscular mycorrhizal fungi and four isolates of the ectomycorrhizal fungus Pisolithus tinctorius (Pers.) Coker and Couch. New Forests 39: 215-230, https://doi.org/10.1007/s11056-009-9165-4

Atkinson, C.J., Fitzgerald, J.D. and Hipps, N.A. (2010). Potential mechanism for achieving agricultural benefits from biochar application to temperate soils: Plant Soil 337: 1-18, https://doi.org/10.1007/s11104-010-0464-5

Balai Penelitian Tanah. (2009). Petunjuk Teknis Edisi 2: Analisis Kimia Tanah, Tanaman, Air dan Pupuk. Bogor (ID): Balai Penelitian tanah. Bogor

Barrios, E. (2007). Soil biota, ecosystem services and land productivity. Ecological Economics 64: 269-285, https://doi.org/10.1016/j.ecolecon.2007.03.004

Boyer, S. and Wratten, S.D. (2009). The potential of earthworms to restore ecosystem services after opencast mining. Basic and Applied Ecology 11: 196-203.
Retrieved from http://esanalysis. colmex.mx/ Sorted\% 20Papers/2010/2010\%20NZL\%20-Biodiv\%20Phys.pdf

Cakyayanti, I.D. and Setiadi, Y. (2014). Evaluasi hasil-hasil penelitian berbagai jenis pohon dalam rangka rehabilitasi lahan tambang mineral di Indonesia (Kajian Pustaka). Jurnal Silvikultur Tropika 5(2): 91-96, Retrieved from http://download.portalgaruda.org/article.php?article= 281996\&val=228\&title=Study\%20Results\%20of\% 20Research\%20about\%20the\%20Growth\%20Rate\% 20of\%20Tree\%20Species\%20in\%20Post-Mining\%20Area

Dharmawan, I.W.S. and Siregar, C.A. (2008). Karbon tanah dan pendugaan karbon tegakan Avicennia marina (Forsk.) Vierh. di Ciasem, Purwakarta. Jurnal Penelitian Hutan dan Konservasi Alam 5(4): 317-328, Retrieved from http://ejournal.forda-mof.org/ejournal-litbang/index.php/ JPHKA/article/view/1161

Frouz, J. and Jilkova, V. (2008). The effect of ants on soil properties and processes (hymenoptera: formicidae). Myrmecological News, 11(11): 191-199, Retrieved from https://www.researchgate.net/profile/Jan_Frouz/ publication/228499939_

The_effect_of_ants_on_soil_properties_and_processes_Hyme noptera_Formicidae/links/00b49525756daaab2d000000/

The-effect-of-ants-on-soilproperties-and-processesHymenoptera-Formicidae.pdf

Gani, A. (2009). Potensi arang hayati "biochar" sebagai komponen teknologi perbaikan produktivitas lahan pertanian. Iptek Tanaman Pangan 4(1): 33-48, Retrieved from http://ejurnal.litbang.pertanian.go.id/index.php/ippan/ article/view/2630

Hanafiah, K. I. (2005). Dasar-Dasar Ilmu Tanah. Jakarta (ID): PT Raja Grafindo Persada.

Hardjowigeno, S. (2003). IImu Tanah Cetakan Kelima. Jakarta (ID): Akademika Pressindo.

Hariz, A.R.M., Azlina, W.A.K.G., Fazly, M.M., Norziana, Z.Z., Ridzuan, M.M.D., Tosiah, S. and Ain, A.B.N. (2015). Local practices for production of rice husk biochar and coconut shell biochar: Production methods, product characteristics, nutrient and field water holding capacity. Journal of tropical agriculture and food science, 43(1): 91-101, Retrieved from http://ejtafs.mardi.gov.my/jtafs/43-1/biochar.pdf

Herdiana, N., Lukman, A.H. and Mulyadi, K. (2008). Pengaruh dosis dan frekuensi aplikasi pemupukan NPK terhadap pertumbuhan bibit Shorea ovalis Korth. (Blume.) asal anakan alam di persemaian. Jurnal Penelitian Hutan dan Konservasi Alam 5(3): 289-296, https://doi.org/10.20886/jphka.2008.5.3.289-296

Kastono, D. (2005). Tanggapan pertumbuhan dan hasil kedelai hitam terhadap penggunaan pupuk organik dan biopestisida. IImu Pertanian 12(2): 103-116, Retrieved from https://scholar.google.com/citations?user $=0 \mathrm{GvHJ}$ _cAAAAJ\&hl=en\#d=gs_md_citad\&p=\&u=\%2Fcitations\%3F view_op\%3Dview_citation\%26hl\%3Den\%26user\% 3D0GvHJ_cAAAAJ\%26citation_for_view\% 3D0GvHJ_cAAAAJ\%3AkNdYIx-mwKoC\%26tzom\%3D-420 
Krisnawati, H., Kallio, M. and Kanninen, M. (2011). Acacia mangium Willd. : Ekologi, Silvikultur, dan Produktivitas. Bogor (ID): CIFOR. https://doi.org/10. 17528/cifor/003479

Kusuma, A.H., Izzati, M. and Saptiningsih, E. (2013). Pengaruh penambahan arang dan abu sekam dengan proporsi yang berbeda terhadap permeabilitas dan porositas tanah liat serta pertumbuhan kacang hijau (Vigna radiata L.). Buletin Anatomi dan Fisiologi, 21(1): 1-9, https://doi.org/10.14710/ baf.v21i1.6260

Liliane, R., Schmidt, I.K., Michelsen, A. and Jonasson, S. (2001). Manipulation of a microbial based soil food web two at artic sites-evidence of species redundancy among nematode fauna. Applied Soil Ecology 17:19-30. Retrieved from https://www.researchgate.net/profile/Abhishek_ Raj15/...soil....Wall.pdf

Lingga, P., and Marsono. (2008). Petunjuk Penggunaan Pupuk. Jakarta (ID): Penebar Swadaya.

Mansur, I. (2013). Teknik Silvikultur untuk Reklamasi Lahan Bekas Tambang. Bogor (ID): Seamo Biotrop

Mattjik, A.A. And Sumertajaya, I.M. (2006). Perancangan Percobaan dengan Aplikasi SAS dan Minitab, Jilid 1. Bogor (ID) : IPB Press.

Mokany, K., Raison, R.J. and Prokushkin, A.S. (2006). Critical analysis of root : shoot ratios in terrestrial biomes. Global Change Biology 12: 84-96, https://doi.org/10.1111/j.13652486.2005.001043.x

Nduwumuremyi, A. (2013). Soil acidification and lime quality: sources of soil acidity, effects on plant nutriens, efficiency of lime and liming requirements. Research and Review: Journal of Agricultural and Allied Sciences 2(4): 26-34, Retrieved from https://www.researchgate.net/ publica-

tion/321385144_Soil_Acidification_and_Lime_Quality_Sour ces_of_Soil_Acidity_Effects_on_Plant_Nutrients_Efficiency_ of_Lime_and_Liming_Requirements

Ogawa, M. and Okimor, I.Y. (2010). Pioneering works in biochar research, Japan. Australian Journal of Soil Research 48: 489-500, Retrieved from https://www.researchgate.net/ scientific-contributions/65730733_Makoto_Ogawa

Oksana, Irfan, M. and Huda, M.U. (2012). Pengaruh alih fungsi lahan hutan menjadi perkebunan kelapa sawit terhadap sifat kimia tanah. Jurnal Agroteknologi 3(1): 29-34, Retrieved from http://ejournal.uin-suska.ac.id/index.php/ agroteknologi/article/view/92

Pereyra, G., Hartmann, H., Michalzik, B., Ziegler, W. and Trumbore, S. (2015). Influence of rhizobia inoculation on biomass gain and tissue nitrogen content of leucaena leucocephala seedlings under drought. Forest 6: 3686-3703, https://doi.org/10.3390/f6103686

Prayudyaningsih, R. (2014). Pertumbuhan semai Alstonia scholaris, Acacia auriculiformis dan Muntingia calabura yang diinokulasi fungi mikoriza arbuskula pada media tanah bekas tambang kapur. Jurnal Penelitian Kehutanan Wallacea 3(1): 13-23, https://doi.org/10.18330/jwallacea. 2014.vol3iss1pp13-23
Rodrigues, S. and Pinto, G.A. S. (2007). Ultrasound extraction of phenolic compounds from coconut (Cocos nucifera) shell powder. Journal of Food Engineering 80: 869-872, https://doi.org/10.1016/j.jfoodeng.2006.08.009

Roidah, I.S. (2013). Manfaat penggunaan pupuk organik untuk kesuburan tanah. Jurnal Universitas Tulungagung Bonorowo 1 (1): 30-42, Retrieved from http://jurnal-unita.org/ index.php/bonorowo/article/view/5/5

Shalsabila, F., Prijono, S. and Kusuma, Z. (2017). Pengaruh aplikasi biochar kulit kakao terhadap kemantapan agregat dan produksi tanaman jagung pada ultisol lampung timur. Jurnal Tanah dan Sumberdaya Lahan 4(1): 473-480, Retrieved from http://jtsl.ub.ac.id/ index.php/jtsl/article/ view/161

Shipitalo, M. J. (2004). Quantifying the effects of earthworms on soil aggregation and porosity. Earthworm ecology 10: 183 -200, Retrieved from https://doc.rero.ch/record/17435/ files/ Shipitalo_Martin__Quantifying_the_Effects_of_Earthworms_20100310.pdf

Singh, A.K., Tripathi, P.N. and Singh, R. (2007). Effect of rhizobium inoculation, nitrogen and phosphorus levels on growth, yield and quality of kharif cowpea (Vigna unguiculata (L.) Walp.). Crop Res. 33: 71-73, https://doi.org/10.20546/ ijcmas.2017.608.115

Siregar, H.M. and Utami, N.K. (2002). Efektivitas pupuk organik dan pupuk $\mathrm{n}$ pada pertumbuhan bibit eboni (Diospyros celebica Bakh.). Berita Biologi 6(2): 283-287, http://dx.doi.org/10.14203/beritabiologi.v6i2.1495

Stell, R.G.D. and Torries, J.H. (1991). Statistical Principles and Procedures, A Biometric Approach. PT Gramedia Pustaka Utama Jakarta, pp. 149-167

Sukandarrumidi. (2009). Bahan Galian Industri. Yogyakarta (ID): UGM Press.

Wadhwa, Z., Srivastava, V., Rani, R., Tanvi, Makkar, K. and Jangra, S. (2017). Isolation and characterization of rhizobium from chickpea (Cicer arietinum). International Journal of Current Microbiology and Applied Sciences, 6(11): 28802893, https://doi.org/10.20546/ijcmas.2017.611.340

Wahyudi, I. (2009). Serapan N tanaman jagung (Zea mays L.) akibat pemberian pupuk guano dan pupuk hijau lamtoro pada ultisol wanga. Jurnal Agroland 16(4): 265-272, http://dx.doi.org/10.14203/beritabiologi.v6i2.1495

Wasis, B, and Andika, A. (2017). Growth response of mahagony seedling (Swietenia macrophylla King.) to addition of coconut shell charcoal and compost on ex-sand mining site of West Java Province in Indonesia. Agriculture and Environmental Science 2(3): 238-243. Retrieved from https:// www.aesacademy.org/journal/volume2/issue3/AAES-0203-018.pdf

Wasis, B. and Noviani, D. (2010). Pengaruh pemberian pupuk NPK dan kompos terhadap pertumbuhan semai jabon (Anthocephalus cadamba Roxb Miq) pada media tanah bekas tambang emas (tailing). Jurnal Ilmu Pertanian Indonesia 15 (1): 14-19. Retrieved from http://journal.ipb.ac.id/ index.php/ JIPI/article/view/6563 
Wasis, B., Winata, B. and Marpaung, D. R. (2018). Impact of land and forest fire on soil fauna diversity in several land cover in Jambi Province, Indonesia. Biodiversitas 10(2): 740 -746, https://doi.org/10.13057/biodiv/d190249

White, P. J. And Broadley, M. R. (2003). Calcium in plant. Annals of Botany 92: 487-511, https://doi.org/10.1093/aob/ mcg164

Wibisono Y. 2009. Metode Statistik. Gadjah Mada University Press. Yokyakarta. pp 529-603.

Widyati, E. (2013). Pentingnya keragaman fungsional organisme tanah terhadap produktifitas lahan. Tekno Hutan Tanaman 6 (1): 29-37, Retrieved from http://forda-mof.org/files/ Tekno_6.1.2013-4.EnnyWidyati.pdf

Wulandari, A.S., Supriyanto, and Febrianingrum, H. W. (2015). Pengaruh kombinasi pemangkasan akar dan sumber inoku- lum ektomikoriza terhadap pertumbuhan bibit melinjo (Gnetum gnemon). Jurnal Ilmu Pertanian Indonesia 20(3): 236 -241, https://doi.org/10.18343/jipi.20.3.236

Wulandari, A.S. and Susanti, S. (2012). Aplikasi Pupuk Daun Organik untuk Meningkatkan Pertumbuhan Bibit Jabon (Anthocephalus cadamba Roxb. Miq.). Jurnal Silvikultur Tropika 3(3): 137-142. Retrieved from http://download.portalgaruda.org/article.php? article $=85269 \& \mathrm{val}=228$

Yamashita, N., Ohta, S. and Hardjono, A. (2008). Soil changes induced by Acacia mangium plantation establishment: comparison with secondary forest and imperata cylindrical grassland soils in South Sumatra, Indonesia. Forest Ecology and Management 254: 362-370, https://doi.org/10.1016/j.foreco.2007.08.012 